\section{Injury on White Oak Seedlings from Herbicide Exposure Simulating Drift}

Jayesh B. Samtani ${ }^{1}$, John B. Masiunas, and James E. Appleby

Department of Natural Resources and Environmental Sciences, University of

Illinois at Urbana-Champaign, 260 ERML, 1201 West Gregory Drive, Urbana, IL 61801

Additional index words. Quercus alba, leaf tatters, 2,4-D ester, acetochlor, atrazine, dicamba, glyphosate, metolachlor

\begin{abstract}
Herbicide drift to landscape and woodland trees is a particular concern in midwestern United States where the topography is relatively flat, large-scale agriculture relies on herbicides, and housing developments and woodlands are intermingled with agricultural fields. Recently, leaf abnormalities (called leaf tatters) have been reported on white oak (Quercus alba L.). We evaluated the effects of field corn herbicides on white oak at the swollen bud, leaf unfolding, and expanded leaf stages. Container-grown white oak seedlings were treated with $1 \%, 10 \%$, and $25 \%$ standard field use rates of $2,4-D$ isooctyl ester, glyphosate, 2,4-D isooctyl ester + glyphosate, dicamba, acetochlor + atrazine, and metolachlor. Loss of interveinal tissues (leaf tatters) occurred after treatment with the chloroacetanilide herbicides, acetochlor ( + atrazine) and metolachlor, only when oaks were in the leaf unfolding stage. No other herbicide caused tatter-like symptoms. Dicamba and 2,4-D ester applied at the leaf unfolding stage caused leaf cupping, downward rolling of leaf margins, elongation of leaf tips, leaf strapping with parallel veination, and initial leaf cupping followed by death of the growing point. Glyphosate applied at either the leaf unfolding or expanded leaf stage caused leaf chlorosis and necrosis, leaf tip browning, and curling of leaves. Herbicide applications near white oak should be timed before leaf unfolding or after the expanded leaf stages.
\end{abstract}

White oak is a valuable forest and landscape species native to the eastern United States (Elias, 1987). Since the early 1980s, loss of interveinal tissues giving leaves a lacy appearance has been reported on white oak (Haugen et al., 2000). In the spring of 2003, Wisconsin nursery inspectors found leaf tatters on oak trees at garden centers [Wisconsin Department of Agriculture, Trade and Consumer Protection (WDATCP), 2003]. Leaf tatters has also been reported in states from Minnesota, south to Missouri, and east to Pennsylvania (Haugen et al., 2000). The problem can affect a substantial portion of a tree's canopy reducing the aesthetic appeal, overall tree vigor, and health. This makes affected trees more susceptible to other stressors such as adverse environments, air pollution, or pests (Haugen et al., 2000).

Haugen et al. (2000) and WDATCP (2003) proposed that insect feeding, environmental factors, or herbicide drift could cause leaf tatters. Our preliminary research eliminated insect feeding as a cause of leaf tatters

Received for publication 10 June 2008. Accepted for publication 2 Aug. 2008.

This study was partly funded by the USDA Forest Service Evaluation Monitoring Program under award numbers AG FS 04-DG-11244225-247 and AG FS 06-DG-11244225-117.

We thank Dawn Refsell and Monica David for assistance with this study and Mason State Nursery in Topeka, IL, for donating the white oak seedlings. We also thank Gary Kling, Margaret Norton, and Dan Anderson for reviewing the manuscript.

${ }^{1}$ To whom reprint requests should be addressed; e-mailmasiunas@uiuc.edu developing leaves, and chlorosis of young leaves. Symptoms were aggravated with increasing rates of glyphosate. Rose treated with reduced rates of 2,4-D or 2,4-D + glyphosate had epinasty of stems and petioles along with leaf crinkling, curling, and cupping. After $10 \mathrm{~d}$, roses treated with the 2,4-D + glyphosate combination had only symptoms consistent with 2,4-D injury (Al-Khatib et al., 1992). On boxelder (Acer negundo L.), leaf blight injury symptoms were caused from exposure to 2,4-D concentrations as low as $0.01 \mu \mathrm{g}$ (Phipps, 1963). Simulated 2,4-D or dicamba drift to soybeans or field bean (Phaseolus vulgaris L.) caused leaf and stem elongation and leaf malformation, including cupping and crinkling (Behrens and Lueschen, 1979; Lyon and Wilson, 1986).

The impact of herbicide drift on native species is difficult to evaluate and quantify compared with annual crop species. Native species are often perennials and present in communities and not in monocultures (Obrigawitch et al., 1998). Also, the effects of herbicide drift on these species can be subtle such as increased mortality, reduced biomass, lower fecundity, and modifications in morphology and development (Freemark and Boutin, 1995; Gove et al., 2007). Herbicide drift can cause alterations of species composition and diversity; devaluation of wildlife habitat, recreational uses, or aesthetic vistas; reduction in timber or wood pulp production; and lower livestock-carrying capacity (Obrigawitch et al., 1998). Although herbicides at recommended rates can selectively affect growth and species composition of seminatural vegetation, knowledge on the impact of sublethal herbicide concentrations is scarce (Marrs et al., 1991). Our objective was to determine the effects of field corn herbicides on white oak at different stages of development.

\section{Materials and Methods} applied to corn in the midwest (U.S. Department of Agriculture, 2006). In Illinois, misapplications of dicamba or 2,4-D (growth regulators) are the most common cause of drift injury complaints (Mohr, 2004). There are no published reports of these specific herbicides causing injury to white oaks but all have caused injury to other plant species. Preemergent applications of acetochlor have injured sorghum [Sorghum bicolor (L.) Moench] (Roeth et al., 1983). Chrysanthemum (Chrysanthemum leucantheum L.) and kale and collards (Brassica oleracea L. var. acephala DC.) were stunted by applications of s-metolachlor (Derr, 1993; Harrison et al., 1998). S-metolachlor caused transient leaf crinkling and malformed growth to some collard and kale cultivars (Harrison et al., 1998).

Simulated glyphosate drift on pepper (Capsicum annuum L.) caused chlorotic terminal buds and later chlorosis of the foliage developing from the buds (Gilreath et al., 2000). Al-Khatib et al. (1992) reported that glyphosate applications to rose (Rosa dilecta) caused leaf distortion, crinkling, cupping in
Two-year-old, bare root white oak seedlings (Mason State Nursery, Topeka, IL) were planted in $8.52-\mathrm{L}$ plastic nursery pots in a potting soil consisting of $65 \%$ pine bark, $15 \%$ peatmoss, and $20 \%$ rice hulls (White Premium Organics, Ottawa, IL). The potting soil was supplemented with $1.8 \mathrm{~kg} \cdot \mathrm{m}^{-3}$ of Peter's starter fertilizer (Scotts Company, Marysville, $\mathrm{OH}), 783 \mathrm{~g} \cdot \mathrm{m}^{-3}$ of dolomitic limestone, and $75.6 \mathrm{~g} \cdot \mathrm{m}^{-3}$ of Aqua-Gro ${ }^{\circledR}$ 2000 G wetting agent (Scotts Company). Seedling root systems were trimmed to remove damaged roots and to fit into the containers. White oak seedlings were planted on 23 and 19 Apr. in 2004 and 2005, respectively. Seedlings were 0.5 to $0.6 \mathrm{~m}$ tall in 2004 and 0.4 to $0.5 \mathrm{~m}$ tall in 2005 . After planting, containers were placed pot to pot until herbicide treatment. Seedlings were hand-watered as needed, visually gauging the moisture needs in the container mix and the appearance of the oak leaves. Every third watering, a Peter's $(20 \mathrm{~N}-20 \mathrm{P}-10 \mathrm{~K})$ liquid fertilizer dissolved in water at $200 \mathrm{ppm} \mathrm{N}$ was applied to supply $\approx 0.35 \mathrm{~g}$ of nitrogen $(\mathrm{N})$ and 
potassium $(\mathrm{K})$ and $0.17 \mathrm{~g}$ of phosphorus $(\mathrm{P})$ per container. Seedlings were placed in an outdoor site $\approx 3 \mathrm{~km}$ from the nearest crop fields. This site was chosen to avoid oak injury from drift of herbicides applied to agricultural fields.

The experiment was a completely random design with seven single-plant replications. The fixed factors were herbicide treatments, rates, and white oak growth stage. We used herbicides commonly applied to corn and previously found to injure plants. We selected the herbicide rates $(1 \%, 10 \%$, and $25 \%$ of a common use rate) based on theoretical modeling of drift and rates used in previous studies (Bhatti et al., 1997; Gilreath et al., 2000; Gove et al., 2007; Kleijn and Snoeijing, 1997). In other simulated drift studies, injury was affected by plant growth stage at the time of herbicide application (Miller et al., 2004). White oak seedlings also undergo distinct growth stages as their buds break dormancy and initiate leaf opening (Dougherty et al., 1979). We chose to treat white oak seedlings at the swollen bud, leaf unfolding, and expanded leaf growth stages (Fig. 1).

Herbicide treatments and rates were: 1) water (control); 2) 2,4-D isooctyl ester at 375 $(25 \%), 150(10 \%)$ and $15(1 \%) \mathrm{g} \cdot \mathrm{ha}^{-1}$ a.i.; 3$)$ glyphosate at 275,110 , and $11 \mathrm{~g} \cdot \mathrm{ha}^{-1}$; 4) 2,4$\mathrm{D}$ isooctyl ester + glyphosate at $200+250,80$ $+100,8+10 \mathrm{~g} \cdot \mathrm{ha}^{-1}$, respectively; 5) dicamba at 175,70 , and $7 \mathrm{~g} \cdot \mathrm{ha}^{-1}+28 \% \mathrm{~N}$ at $4.7 \mathrm{~L} \cdot \mathrm{ha}^{-1}$ $+0.8 \mathrm{~L} \cdot \mathrm{ha}^{-1}$ of nonionic surfactant (Activator 90, Greeley, CO); 6) acetochlor + atrazine at $697+275,279+110,28+11$ g.ha ${ }^{-1}$, respectively; and 7) metolachlor at 500, 200 , and $20 \mathrm{~g} \cdot \mathrm{ha}^{-1}$. Herbicides were applied at the Plant Care Facility of the University of Illinois as over-the-top spray to the oaks using a compressed air sprayer equipped with a single 80015 EVS nozzle (Spraying Systems, Wheaton, IL) delivering $187 \mathrm{~L} \cdot \mathrm{ha}^{-1}$ at $207 \mathrm{kPa}$. Oaks were treated on 5 and 3 May (swollen bud), 10 and 11 May (leaf unfolding), and 1 June and 31 May (expanded leaf) in 2004 and 2005, respectively. Although herbicide application dates differed between growth stages, all oak seedlings were treated under similar environmental conditions in the greenhouse.

After the herbicides dried, seedlings were moved back to the outdoor site and spaced $45 \times 45 \mathrm{~cm}$ center to center. Seedlings were watered and fertilized as described previously. Seedlings were photographed to document injury symptoms. Every $7 \mathrm{~d}$, the primary author visually rated the proportion of shoot tissue affected by herbicide injury $(1=$ no injury to $10=$ all plant tissue injured $)$. The repeated ratings documented injury development, the extent of injury, and the rate of recovery. In 2005, the primary author also specifically rated loss of interveinal tissues $(1=$ no tatters to $5=$ all leaves are skeletonized).

Herbicides often cause chlorosis, browning, and necrosis of leaf tissue that can be quantified by measuring leaf color. On 10 and 13 June, 15 and 13 July, and 13 and 10 Aug., in 2004 and 2005, respectively, we used a Single Photon Avalanche Diode (SPAD) meter (SPAD-502; Spectrum Technologies Inc., Plainfield, IL) to measure the greenness of the first fully expanded, mature leaf, from the terminal tip. For better accuracy, five readings were made on the selected leaf and averaged. Starting on 19 Aug. 2004 and 12 Aug. 2005, all the leaves from each oak tree were harvested and the petioles removed. Total leaf area was measured using a LI3100 leaf area meter (LI-COR, Inc., Lincoln, $\mathrm{NE}$ ).
Most of the visual injury was observed when white oak seedlings were treated at the leaf unfolding stage. Hence, the visual and tatter ratings are presented as 15,45 , and $90 \mathrm{~d}$ after treatment (DAT) at the leaf unfolding stage. Data were analyzed with the Proc Mixed procedure in SAS (release 8.02; SAS Institute Inc., Cary, NC). The least significant difference test $(P=0.05)$ was used for mean separation and the letters indicating significant differences were assigned using the macro "PDMIX 800" procedure (Saxton, 1998).

\section{Results and Discussion}

Visual injury to white oak seedlings was dependent on year, herbicide treatment, concentration, growth stage, and rating date. Visual injury developed within $5 \mathrm{~d}$ and was still evident 90 DAT at the leaf unfolding stage. Treatment at the swollen bud stage did not consistently injure seedlings compared with treatment at the other growth stages. The type, intensity, and persistence of injury symptoms differed among herbicides. Injury symptoms from 2,4-D ester or dicamba were leaf cupping, leaf margins rolling downward, elongation of leaf tips, and a few seedlings with leaf strapping (parallel veination) or initial leaf cupping followed by death of the growing point (Fig. 2A-C). Leaf cupping, rolling, and strapping are common symptoms of growth regulator herbicide drift (Bhatti et al., 1997; Lyon and Wilson, 1986). When applied at the expanded leaf stage, 2,4-D ester and dicamba caused leaf wilting and yellowing or browning.

Seedlings treated with glyphosate at either the leaf unfolding or expanded leaf stage had leaf yellowing and browning, leaf tip browning, and abnormal leaves (Fig. 2D).
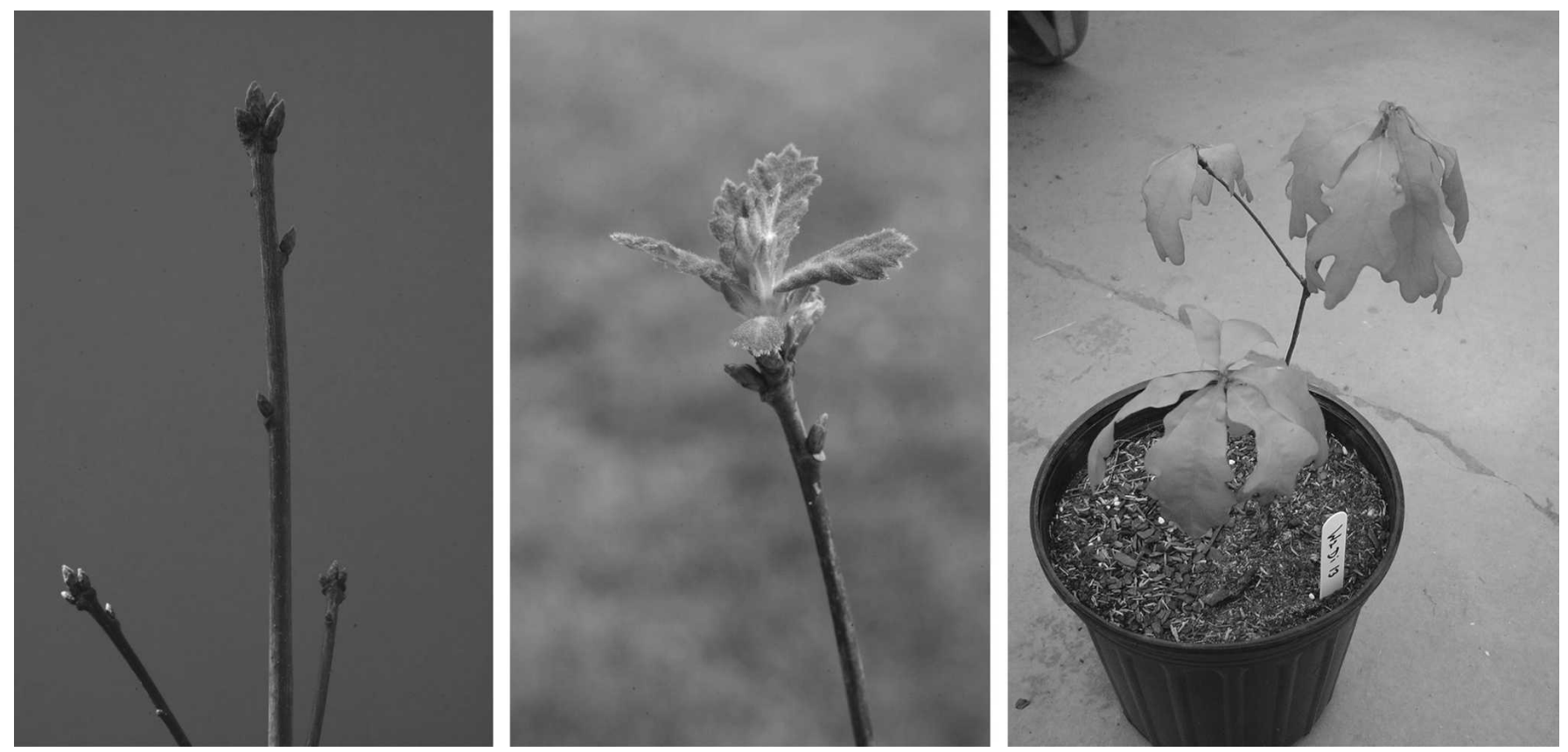

Fig. 1. The swollen bud, leaf unfolding, and expanded leaf growth stages of white oak (left to right). 

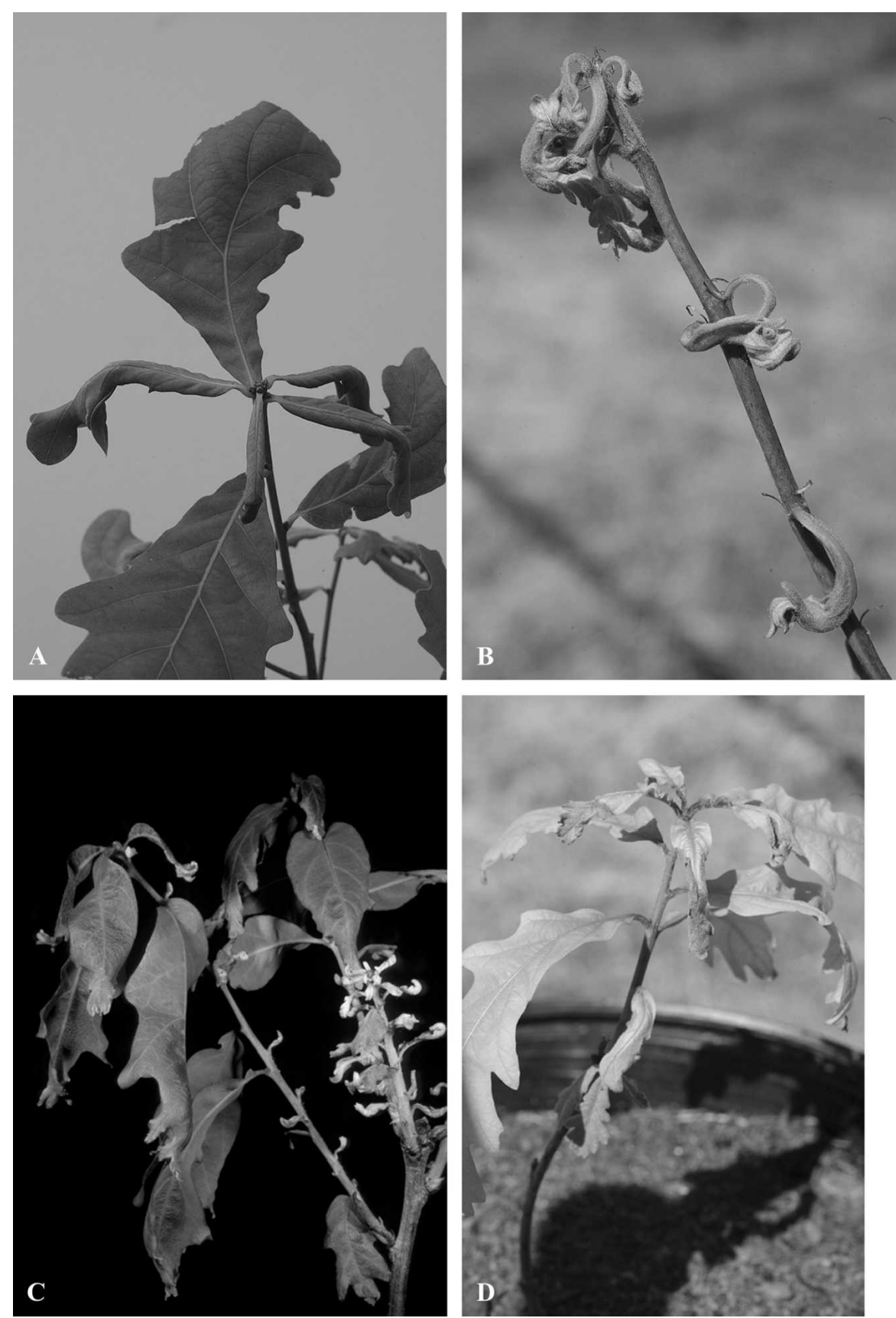

Fig. 2. The injury symptoms from herbicides applied to white oak at the leaf unfolding growth stage. Leaf cupping, epinasty, strapping, and curling caused by $2.4-\mathrm{D}$ ester at (A) $1 \%$ field use rate, $88 \mathrm{~d}$ after treatment (DAT) and (B) 25\% field use rate 16 DAT. (C) Distorted, leathery leaves, smaller leaves with cupping and epinasty caused by dicamba at $25 \%$ field use rate 87 DAT. (D) Death of the shoot apical meristem and leaf cupping, chlorosis, and necrosis caused by glyphosate at $25 \%$ field use rate 16 DAT.

Gilreath et al. (2000) and Miller et al. (2004) reported similar injury symptoms from simulated glyphosate drift on peppers and cotton (Gossypium spp.). Symptoms on oak seedlings treated with 2,4-D ester + glyphosate were a combination of those for each herbicide, including leaf cupping and rolling, yellowing, abnormal leaf tips, and twisted stems followed by reduced plant growth and leaf death. Bhatti et al. (1997) also observed leaf death from simulated 2,4-D + glyphosate drift on grapevines (Vitis vinifera L.).

Acetochlor + atrazine and metolachlor applied at the oak leaf unfolding stage caused loss of interveinal tissues giving the leaves a lacy appearance (Fig. 3). These leaves were also similar to leaves on mature white oak trees we found affected by leaf tatters in landscapes. After $\approx 45$ to $65 \mathrm{~d}$, the seedlings had a second flush of normal-appearing leaves. Haugen et al. (2000) and WDATCP (2003) also reported that tatters only affected the first flush of leaves.

At 15 DAT, year, herbicide, concentration, and growth stage interacted to determine injury (Table 1). In both years, seedlings treated at the leaf unfolding stage with 2,4-D ester, acetochlor + atrazine, and
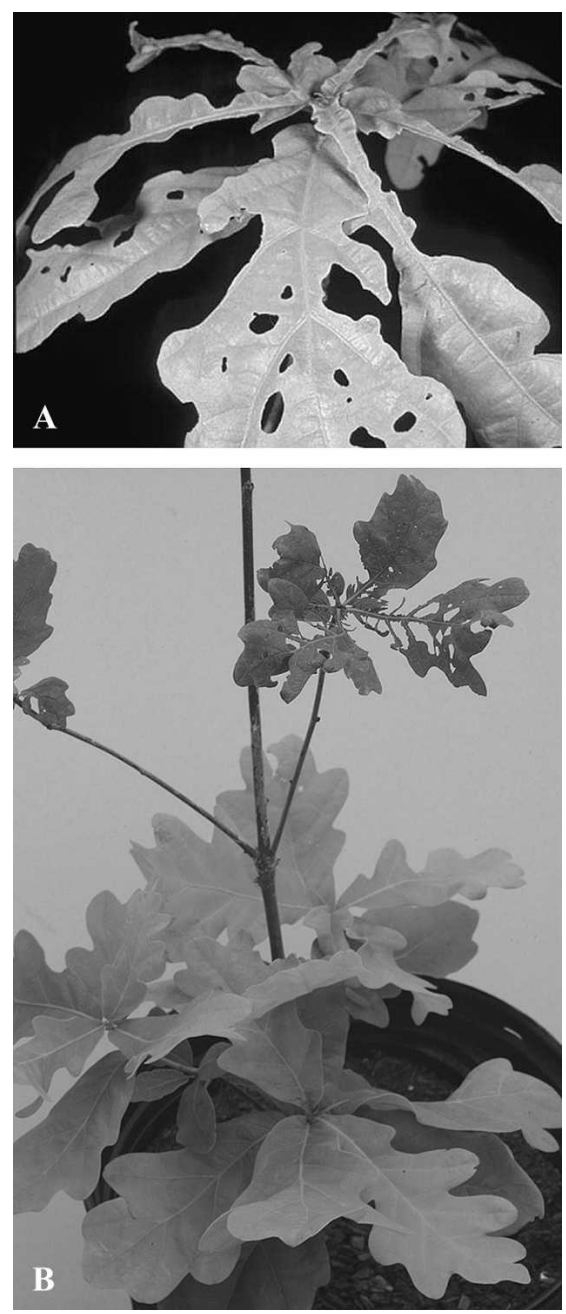

Fig. 3. (A) Leaf injury $15 \mathrm{~d}$ after treatment at the leaf unfolding stage with metolachlor at $1 \%(20$ $\mathrm{g} \cdot \mathrm{ha}^{-1}$ ) of the field use rate. (B) The normal, noninjured second flush of leaves (bottom) with the lacy or skeletonized first flush of leaves (upper).

metolachlor at all concentrations were injured compared with the control. The threshold for 2,4-D ester, acetochlor + atrazine, and metolachlor injury of oak seedlings was less than our lowest concentration. Dicamba at $1 \%$ field rate and glyphosate at 1 and $10 \%$ field rate did not injure oak seedlings compared with the control. Bhatti et al. (1997) found 2,4-D at all rates ( $1 \%$ to $33 \%$ ) and glyphosate only at $33 \%$ maximum use rate caused visual injury to grapes. In $2004,2,4-\mathrm{D}$ ester + glyphosate at $1 \%$ field rate did not injure seedlings, whereas all rates injured seedlings in 2005. Variation in temperature and humidity before application may explain the difference in 2,4-D ester + glyphosate injury between years (Wills, 1978). The average temperature for $10 \mathrm{~d}$ before treatment at the leaf unfolding stage was 19.7 and $10.7^{\circ} \mathrm{C}$ in 2004 and 2005, respectively. Wills (1978) reported more glyphosate injury from applications at cooler temperatures because of greater herbicide translocation.

At 45 DAT, visual injury was determined by the interaction of year, herbicide, 
Table 1. Visual ratings of injury to white oak seedlings, $15 \mathrm{~d}$ after treatment (DAT) at the leaf unfolding stage (20 to 22 DAT at the swollen bud stage).

\begin{tabular}{|c|c|c|c|c|c|c|}
\hline \multirow[b]{2}{*}{ Herbicide treatment ${ }^{y}$} & \multicolumn{3}{|c|}{ Swollen bud } & \multicolumn{3}{|c|}{ Leaf unfolding ${ }^{\mathrm{z}}$} \\
\hline & $1 \%$ & $10 \%$ & $25 \%$ & $1 \%$ & $10 \%$ & $25 \%$ \\
\hline & \multicolumn{6}{|c|}{2004} \\
\hline Control & \multicolumn{3}{|c|}{ - -------------- $1.61^{\mathrm{xw}}$--------------- } & \multicolumn{3}{|c|}{--------------1.9 kl ------------- } \\
\hline 2,4-D ester & $4.0 \mathrm{c}-\mathrm{k}$ & $3.4 \mathrm{e}-1$ & $2.9 \mathrm{~g}-1$ & $4.4 \mathrm{~b}-\mathrm{i}$ & $6.6 \mathrm{ab}$ & $7.3 \mathrm{a}$ \\
\hline 2,4-D ester + glyphosate & $3.1 \mathrm{~g}-1$ & $2.4 \mathrm{i}-1$ & $3.1 \mathrm{~g}-1$ & $3.1 \mathrm{~g}-1$ & $4.1 \mathrm{c}-\mathrm{j}$ & $5.6 \mathrm{a}-\mathrm{e}$ \\
\hline Dicamba & $2.4 \mathrm{i}-1$ & $4.3 \mathrm{c}-\mathrm{i}$ & $3.9 \mathrm{c}-1$ & $2.7 \mathrm{~h}-1$ & $5.6 \mathrm{a}-\mathrm{e}$ & $5.0 \mathrm{~b}-\mathrm{g}$ \\
\hline Glyphosate & $2.0 \mathrm{j}-1$ & $3.6 \mathrm{~d}-1$ & $4.0 \mathrm{c}-\mathrm{k}$ & $3.1 \mathrm{~g}-1$ & $3.3 \mathrm{f}-1$ & $4.9 \mathrm{~b}-\mathrm{h}$ \\
\hline Acetochlor + atrazine & $4.9 \mathrm{~b}-\mathrm{h}$ & $3.7 \mathrm{c}-1$ & $3.7 \mathrm{c}-1$ & $5.7 \mathrm{a}-\mathrm{d}$ & $4.4 \mathrm{~b}-\mathrm{i}$ & $5.9 \mathrm{a}-\mathrm{c}$ \\
\hline \multirow[t]{2}{*}{ Metolachlor } & $3.6 \mathrm{~d}-1$ & $4.0 \mathrm{c}-\mathrm{k}$ & $3.6 \mathrm{~d}-1$ & $4.9 \mathrm{~b}-\mathrm{h}$ & $5.4 \mathrm{a}-\mathrm{f}$ & $4.9 \mathrm{~b}-\mathrm{h}$ \\
\hline & \multicolumn{6}{|c|}{2005} \\
\hline Control & \multicolumn{3}{|c|}{ - } & \multicolumn{3}{|c|}{----------------- 1.11 ---------------- } \\
\hline 2,4-D ester & 1.31 & $2.0 \mathrm{i}-1$ & $4.6 \mathrm{e}-\mathrm{g}$ & $6.3 \mathrm{~b}-\mathrm{d}$ & $7.3 \mathrm{ac}$ & $8.1 \mathrm{a}$ \\
\hline 2,4-D ester + glyphosate & $1.9 \mathrm{j}-1$ & $2.3 \mathrm{~h}-1$ & $2.4 \mathrm{~h}-1$ & $3.4 \mathrm{~g}-\mathrm{i}$ & $6.9 \mathrm{a}-\mathrm{c}$ & $7.6 \mathrm{ab}$ \\
\hline Dicamba & $2.4 \mathrm{~h}-1$ & $3.1 \mathrm{~g}-\mathrm{j}$ & $2.1 \mathrm{i}-1$ & $1.7 \mathrm{j}-1$ & $6.0 \mathrm{c}-\mathrm{e}$ & $7.4 \mathrm{a}-\mathrm{c}$ \\
\hline Glyphosate & $2.9 \mathrm{~h}-\mathrm{k}$ & $1.9 \mathrm{j}-1$ & $2.3 \mathrm{~h}-1$ & 1.01 & $2.0 \mathrm{i}-1$ & $3.7 \mathrm{f}-\mathrm{h}$ \\
\hline Acetochlor + atrazine & $1.7 \mathrm{j}-1$ & $2.3 \mathrm{~h}-1$ & $1.9 \mathrm{j}-1$ & $3.0 \mathrm{~h}-\mathrm{k}$ & $7.0 \mathrm{a}-\mathrm{c}$ & $7.7 \mathrm{ab}$ \\
\hline Metolachlor & $2.0 \mathrm{i}-1$ & $1.9 \mathrm{j}-1$ & $1.6 \mathrm{kl}$ & $5.0 \mathrm{~d}-\mathrm{f}$ & $6.6 \mathrm{bc}$ & $6.6 \mathrm{bc}$ \\
\hline
\end{tabular}

${ }^{2}$ Injury was rated before the seedlings had reached the expanded leaf phase of growth.

${ }^{\mathrm{y}}$ Standard field use rate of herbicides include 2,4-D ester at $1500 \mathrm{~g} \cdot \mathrm{ha}^{-1}$ a.i., glyphosate at $1100 \mathrm{~g} \cdot \mathrm{ha}^{-1}, 2,4$ D ester + glyphosate at $800 \mathrm{~g} \cdot \mathrm{ha}^{-1}+1000 \mathrm{~g} \cdot \mathrm{ha}^{-1}$, respectively; dicamba at $700 \mathrm{~g} \cdot \mathrm{ha}^{-1}+28 \%$ nitrogen at 4.7 $\mathrm{L} \cdot \mathrm{ha}^{-1}+0.8 \mathrm{~L} \cdot \mathrm{ha}^{-1}$ nonionic surfactant, acetochlor + atrazine at $2786 \mathrm{~g} \cdot \mathrm{ha}^{-1}+1102 \mathrm{~g} \cdot \mathrm{ha}^{-1}$, respectively; and metolachlor at $2000 \mathrm{~g} \cdot \mathrm{ha}^{-1}$.

${ }^{\mathrm{x}}$ Injury visual ratings from $1=$ no injury to $10=$ all plant tissue injured.

wMeans with the same letter across all columns for each year are not significantly different using least significant difference in proc mixed at $P \leq 0.05$.

concentration, and growth stage (Tables 2 and 3 ). Herbicide injury from some treatments such as 2,4-D ester continued to develop after the 15 DAT rating. Also in 2004, Japanese beetle (Popillia japonica Newman) feeding occurred, $\approx 35$ DAT, before insecticide treatments. The Japanese beetle feeding caused oak leaf injury. In
2005, an insecticide was applied before Japanese beetle feeding to prevent leaf injury.

In 2004, most oak seedlings had recovered from initial herbicide injury (Table 2). Injury remaining at 45 DAT was not consistently the greatest at the highest herbicide concentrations. For example, seedlings trea- ted at the swollen bud stage with 2,4-D ester at $1 \%$ or $10 \%$ field rate (visual rating of 4.6 and 4.9 , respectively) had more injury than with $2,4-D$ at $25 \%$ field rate (visual rating of 3.4). At the swollen bud stage, the bud structure and lack of green tissue may affect herbicide absorption, time for injury to develop, and ability to recover from injury compared with other growth stages. Higher 2,4-D ester concentrations may inhibit absorption and translocation or stimulate metabolism.

In 2005, most seedlings were still injured at 45 DAT. Seedlings treated at all growth stages with glyphosate at $25 \%$ of the standard field rate still had more injury than the control (Table 3 ). Oak recovery from injury at the leaf unfolding stage caused by 2,4-D ester + glyphosate at $1 \%$ and $10 \%$ of field rate was greater than recovery from 2,4-D ester alone at the same concentrations. It is not clear if glyphosate reduced translocation of 2,4-D. Flint and Barrett (1989) found that in most cases, 2,4-D translocation was inhibited by addition of glyphosate and more 2,4-D was retained in the presence of glyphosate on treated leaf compared with 2,4-D alone. However, including glyphosate with 2,4-D increased 2,4-D absorption and translocation in leafy spurge (Euphorbia esula L.) at the vegetative-to-flowering growth stage (Lym, 2000).

The interaction of year, herbicide, and growth stage affected visual injury at 90 DAT (Table 4). At the swollen bud stage, only oak seedlings treated with glyphosate were injured greater than the control. Glyphosate

Table 2. Visual ratings of injury to white oak seedlings in 2004 at $45 \mathrm{~d}$ after treatment (DAT) at the leaf unfolding stage (50 to 52 DAT at the swollen bud stage and 25 DAT at the expanded leaf stage).

\begin{tabular}{|c|c|c|c|c|c|c|c|c|c|}
\hline \multirow[b]{2}{*}{ Herbicide treatment ${ }^{z}$} & \multicolumn{3}{|c|}{ Swollen bud } & \multicolumn{3}{|c|}{ Leaf unfolding } & \multicolumn{3}{|c|}{ Expanded leaf } \\
\hline & $1 \%$ & $10 \%$ & $25 \%$ & $1 \%$ & $10 \%$ & $25 \%$ & $1 \%$ & $10 \%$ & $25 \%$ \\
\hline 2,4-D ester & $4.6 \mathrm{a}-\mathrm{e}$ & $4.9 \mathrm{a}-\mathrm{c}$ & $3.4 \mathrm{fg}$ & $4.4 \mathrm{a}-\mathrm{f}$ & $5.0 \mathrm{ab}$ & $5.0 \mathrm{ab}$ & $4.0 \mathrm{~b}-\mathrm{g}$ & $4.7 \mathrm{a}-\mathrm{d}$ & $5.0 \mathrm{ab}$ \\
\hline Dicamba & $3.6 \mathrm{e}-\mathrm{g}$ & $3.7 \mathrm{~d}-\mathrm{g}$ & $3.3 \mathrm{~g}$ & $3.7 \mathrm{~d}-\mathrm{g}$ & $4.4 \mathrm{a}-\mathrm{f}$ & $4.6 \mathrm{a}-\mathrm{e}$ & $3.9 \mathrm{c}-\mathrm{g}$ & $4.7 \mathrm{a}-\mathrm{d}$ & $4.3 \mathrm{a}-\mathrm{g}$ \\
\hline Glyphosate & $3.4 \mathrm{fg}$ & $3.7 \mathrm{~d}-\mathrm{g}$ & $4.3 \mathrm{a}-\mathrm{g}$ & $3.4 \mathrm{fg}$ & $4.3 \mathrm{a}-\mathrm{g}$ & $5.0 \mathrm{ab}$ & $4.4 \mathrm{a}-\mathrm{f}$ & $3.7 \mathrm{~d}-\mathrm{g}$ & $4.3 \mathrm{a}-\mathrm{g}$ \\
\hline Acetochlor + atrazine & $4.0 \mathrm{~b}-\mathrm{g}$ & $3.3 \mathrm{~g}$ & $4.0 \mathrm{~b}-\mathrm{g}$ & $5.1 \mathrm{a}$ & $4.9 \mathrm{a}-\mathrm{c}$ & $4.9 \mathrm{a}-\mathrm{c}$ & $3.6 \mathrm{e}-\mathrm{g}$ & $3.3 \mathrm{~g}$ & $4.7 \mathrm{a}-\mathrm{c}$ \\
\hline Metolachlor & $3.7 \mathrm{~d}-\mathrm{g}$ & $4.3 \mathrm{a}-\mathrm{g}$ & $3.6 \mathrm{e}-\mathrm{g}$ & $5.0 \mathrm{ab}$ & $5.1 \mathrm{a}$ & $4.0 \mathrm{~b}-\mathrm{g}$ & $4.3 \mathrm{a}-\mathrm{g}$ & $4.3 \mathrm{a}-\mathrm{g}$ & $3.9 \mathrm{c}-\mathrm{g}$ \\
\hline
\end{tabular}

${ }^{2}$ Standard field use rate of herbicides include 2,4-D ester at $1500 \mathrm{~g} \cdot \mathrm{ha}^{-1}$ a.i., glyphosate at $1100 \mathrm{~g} \cdot \mathrm{ha}^{-1}, 2,4-\mathrm{D}$ ester + glyphosate at $800 \mathrm{~g} \cdot \mathrm{ha}^{-1}+1000 \mathrm{~g} \cdot \mathrm{ha}^{-1}$ respectively; dicamba at $700 \mathrm{~g} \cdot \mathrm{ha}^{-1}+28 \%$ nitrogen at $4.7 \mathrm{~L} \cdot \mathrm{ha}^{-1}+0.8 \mathrm{~L} \cdot \mathrm{ha}^{-1}$ nonionic surfactant, acetochlor + atrazine at $2786 \mathrm{~g} \cdot \mathrm{ha}^{-1}+1102 \mathrm{~g} \cdot \mathrm{ha} \mathrm{a}^{-1}$, respectively; and metolachlor at $2000 \mathrm{~g} \cdot \mathrm{ha}^{-1}$.

${ }^{\mathrm{y}}$ Injury visual ratings from $1=$ no injury to $10=$ all plant tissue injured.

${ }^{\times}$Means with the same letter across all columns are not significantly different using least significant difference in proc mixed at $P \leq 0.05$.

Table 3. Visual ratings of injury to white oak seedlings in 2005 at $45 \mathrm{~d}$ after treatment (DAT) at the leaf unfolding stage (50 to $52 \mathrm{DAT}$ at the swollen bud stage and 25 DAT at the expanded leaf stage).

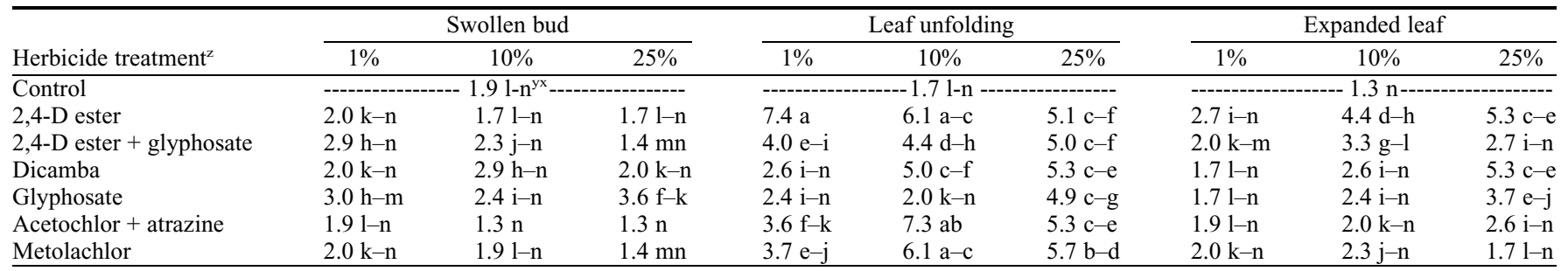

${ }^{\mathrm{z}}$ Standard field use rate of herbicides include 2,4-D ester at $1500 \mathrm{~g} \cdot \mathrm{ha}^{-1}$ a.i., glyphosate at $1100 \mathrm{~g} \cdot \mathrm{ha}^{-1}, 2,4-\mathrm{D}$ ester $+\mathrm{glyphosate}$ at $800 \mathrm{~g} \cdot \mathrm{ha} \mathrm{P}^{-1}+1000 \mathrm{~g} \cdot \mathrm{ha}^{-1}$, respectively; dicamba at $700 \mathrm{~g} \cdot \mathrm{ha}^{-1}+28 \%$ nitrogen at $4.7 \mathrm{~L} \cdot \mathrm{ha}^{-1}+0.8 \mathrm{~L} \cdot \mathrm{ha}^{-1}$ nonionic surfactant, acetochlor + atrazine at $2786 \mathrm{~g} \cdot \mathrm{ha} \mathrm{a}^{-1}+1102 \mathrm{~g} \cdot \mathrm{ha} \mathrm{a}^{-1}$, respectively; and metolachlor at $2000 \mathrm{~g} \cdot \mathrm{ha}^{-1}$.

${ }^{\mathrm{y}}$ Injury visual ratings from $1=$ no injury to $10=$ all plant tissue injured.

${ }^{\times}$Means with the same letter across all columns are not significantly different using least significant difference in proc mixed at $P \leq 0.05$. 
Table 4. Visual ratings of injury to white oak seedlings $90 \mathrm{~d}$ after treatment (DAT) at the leaf unfolding stage (100 to 102 DAT at the swollen bud stage and 70 DAT at the expanded leaf stage).

\begin{tabular}{|c|c|c|c|c|c|c|}
\hline \multirow[b]{2}{*}{ Herbicide treatment $^{z}$} & \multicolumn{2}{|c|}{ Swollen bud } & \multicolumn{2}{|c|}{ Leaf unfolding } & \multicolumn{2}{|c|}{ Expanded leaf } \\
\hline & 2004 & 2005 & 2004 & 2005 & 2004 & 2005 \\
\hline Control & $3.8 \mathrm{de}^{\mathrm{yx}}$ & $1.6 \mathrm{j}$ & $3.9 \mathrm{~cd}$ & $1.6 \mathrm{j}$ & $4.0 \mathrm{~b}-\mathrm{d}$ & $1.9 \mathrm{ij}$ \\
\hline 2,4-D ester & $4.2 \mathrm{~b}-\mathrm{d}$ & $1.6 \mathrm{j}$ & $4.5 \mathrm{bc}$ & $4.4 \mathrm{bc}$ & $4.5 \mathrm{bc}$ & $3.7 \mathrm{de}$ \\
\hline 2,4-D ester + glyphosate & $4.2 \mathrm{~b}-\mathrm{d}$ & $2.2 \mathrm{~g}-\mathrm{j}$ & $4.4 b-d$ & $3.7 \mathrm{de}$ & $4.4 \mathrm{bc}$ & $2.3 \mathrm{~g}-\mathrm{i}$ \\
\hline Dicamba & $4.1 \mathrm{~b}-\mathrm{d}$ & $2.2 \mathrm{~g}-\mathrm{j}$ & $4.3 \mathrm{~b}-\mathrm{d}$ & $3.2 \mathrm{ef}$ & $4.7 \mathrm{~b}$ & $2.6 \mathrm{f}-\mathrm{h}$ \\
\hline Glyphosate & $4.7 \mathrm{~b}$ & $2.7 \mathrm{fg}$ & $4.6 \mathrm{bc}$ & $2.6 \mathrm{f}-\mathrm{h}$ & $4.5 \mathrm{bc}$ & $2.4 \mathrm{~g}-\mathrm{i}$ \\
\hline Acetochlor + atrazine & $4.2 \mathrm{~b}-\mathrm{d}$ & $1.6 \mathrm{j}$ & $5.5 \mathrm{a}$ & $4.7 \mathrm{~b}$ & $4.6 \mathrm{bc}$ & $2.1 \mathrm{~g}-\mathrm{j}$ \\
\hline Metolachlor & $4.1 \mathrm{~b}-\mathrm{d}$ & $1.8 \mathrm{ij}$ & $4.7 \mathrm{~b}$ & $4.0 \mathrm{~cd}$ & $4.1 \mathrm{~b}-\mathrm{d}$ & $2.0 \mathrm{~h}-\mathrm{j}$ \\
\hline
\end{tabular}

${ }^{\text {z}}$ Standard field use rate of herbicides include $2,4-\mathrm{D}$ ester at $1500 \mathrm{~g} \cdot \mathrm{ha}^{-1}$ a.i., glyphosate at $1100 \mathrm{~g} \cdot \mathrm{ha}^{-1}, 2,4$ D ester + glyphosate at $800 \mathrm{~g} \cdot \mathrm{ha}^{-1}+1000 \mathrm{~g} \cdot \mathrm{ha}^{-1}$, respectively; dicamba at $700 \mathrm{~g} \cdot \mathrm{ha}^{-1}+28 \%$ nitrogen at 4.7 $\mathrm{L} \cdot \mathrm{ha}^{-1}+0.8 \mathrm{~L} \cdot \mathrm{ha}^{-1}$ nonionic surfactant, acetochlor + atrazine at $2786 \mathrm{~g} \cdot \mathrm{ha}^{-1}+1102 \mathrm{~g} \cdot \mathrm{ha}^{-1}$, respectively; and metolachlor at $2000 \mathrm{~g} \cdot \mathrm{ha}^{-1}$.

${ }^{\mathrm{y}}$ Injury visual ratings from $1=$ no injury to $10=$ all plant tissue injured.

${ }^{x}$ Means with the same letter across columns are not significantly different using least significant difference in proc mixed at $P \leq 0.05$.

injury developed and plants recovered more slowly than other herbicide treatments. Miller et al. (2004) also reported that glyphosate injury developed slowly. The initial leaf tatters injury from acetochlor + atrazine and metolachlor remained on the trees even after a second flush of uninjured leaves. We also observed later leaf flushes without injury on mature white oak trees with leaf tatters. Loss of interveinal tissues of the first flush of leaves (leaf tatters) only occurred on seedlings treated with acetochlor + atrazine or metolachlor at the leaf unfolding stage (Fig. 3).

Few treatments affected leaf greenness (SPAD). In June, although the herbicide and concentration interaction was significant, only $2,4-\mathrm{D}$ ester at the $25 \%$ rate had lower SPAD readings compared with the control (data table not shown). This could be the result of leaf yellowing on seedlings treated with 2,4-D ester. In July and August, herbicide treatment did not affect leaf greenness compared with the control. Although the SPAD meter is a useful instrument for nondestructive determination of total chlorophyll content, on broadleaf plants, it has limitations (i.e., requirement for multiple measurements, influence of leaf thickness) (Campbell et al., 1990; Chapman and Barreto, 1997). SPAD measurements of leaf greenness are not useful for quantifying herbicide injury on oak seedlings.

Injury symptoms from 2,4-D and dicamba applications to white oak are consistent with injury reported in other studies. Leaf yellowing and browning and abnormal growth from glyphosate were also reported in other studies. Our research is the first to document leaf tatter injury from exposure of oaks to chloroacetanilide herbicides. Leaf tatters decrease the aesthetic value of oaks, making containerized oak seedlings unmarketable. Further research is needed to determine how multiple occurrences of leaf tatters affect white oak stands. Additional studies are needed to determine how atrazine influences leaf tatters and if lower rates of chloroacetanilide herbicides cause injury.

\section{Literature Cited}

Al-Khatib, K., R. Parker, and E.P. Fuerst. 1992. Rose (Rosa dilecta) response to simulated herbicide drift. HortTechnology 2:394-398.

Behrens, R. and W.E. Lueschen. 1979. Dicamba volatility. Weed Sci. 27:486-493.

Bhatti, M.A., K. Al-Khatib, and R. Parker. 1997. Wine grape (Vitis vinifera) response to fall exposure of simulated drift from selected herbicides. Weed Technol. 11:532-536.

Campbell, R.J., K.N. Mobley, R.P. Marini, and D.G. Pfeiffer. 1990. Growing conditions alter the relationship between SPAD-501 values and apple leaf chlorophyll. HortScience 25:330 331.

Chapman, S.C. and H.J. Barreto. 1997. Using a chlorophyll meter to estimate specific leaf nitrogen of tropical maize during vegetative growth. Agron. J. 89:557-562.

Derr, J.F. 1993. Wildflower tolerance to metolachlor and metolachlor combined with other broadleaf herbicides. HortScience 28:10231026.

Dougherty, P.M., R.O. Teskey, J.E. Phelps, and T.M. Hinckley. 1979. Net photosynthesis and early growth trends of dominant white oak (Quercus alba L.). Plant Physiol. 64:930-935.

Elias, T.S. 1987. The complete trees of North America. Crown, New York, NY.

Flint, J.L. and M. Barrett. 1989. Effects of glyphosate combinations with 2,4-D or dicamba on field bindweed (Convolvulus arvensis). Weed Sci. 37:12-18

Freemark, K. and C. Boutin. 1995. Impacts of agricultural herbicide use on terrestrial wildlife in temperate landscapes: A review with special reference to North America. Agr. Ecosystems and Environ 52:67-91.

Gilreath, J.P., C.A. Chase, and S.J. Locascio. 2000. Phytotoxic effects of glyphosate on pepper
(Capsicum annuum). Weed Technol. 14:488494

Gove, B., S.A. Power, G.P. Buckley, and J. Ghazoul. 2007. Effects of herbicide spray drift and fertilizer overspread on selected species of woodland ground flora: Comparison between short-term and long-term impact assessments and field surveys. J. Appl. Ecol. 44:374-384.

Harrison, H.F., M.W. Farnham, and J.K. Peterson. 1998. Differential response of collard and kale cultivars to preemergence application of metolachlor. Crop Prot. 17:293-297.

Haugen, L., P. Marshall, J.C. Carlson, M. Vitosh, and E. Hayes. 2000. Oak tatters. United States Department of Agriculture Pest Alert. 29 July 2008. <http://www.na.fs.fed.us/spfo/pubs/pest_ al/oaktatters/oaktatters.htm>.

Kleijn, D. and G.I.J. Snoeijing. 1997. Field boundary vegetation and the effects of agrochemical drift: Botanical change caused by low levels of herbicide and fertilizer. J. Appl. Ecol. 34:1413-1425.

Lym, R.G. 2000. Leafy spurge (Euphorbia esula) control with glyphosate plus 2,4-D. J. Range Manage. 53:68-72.

Lyon, D.J. and R.G. Wilson. 1986. Sensitivity of fieldbeans (Phaseolus vulgaris) to reduced rates of 2, 4-D and dicamba. Weed Sci. 34:953-956.

Marrs, R.H., A.J. Frost, and R.A. Plant. 1991. Effects of herbicide spray drift on selected species of nature conservation interest: The effects of plant age and surrounding vegetation structure. Environ. Pollut. 69:223-235.

Miller, D.K., R.G. Downer, B.R. Leonard, E.M. Holman, and S.T. Kelly. 2004. Response of nonglyphosate-resistant cotton to reduced rates of glyphosate. Weed Sci. 52:178-182.

Mohr, M. 2004. Reducing pesticide drift: Specialty crops and conventional crops as good neighbors. University of Illinois Extension. 29 July 2008. <http://www.specialtygrowers.org/ releases/ReducingPesticideDrift.pdf $>$.

Obrigawitch, T.T., G. Cook, and J. Wetherington. 1998. Assessment of effects on non-target plants from sulfonylurea herbicides using field approaches. Pestic. Sci. 52:199-217.

Phipps, H.M. 1963. The role of 2,4-D in the appearance of a leaf blight of some plains tree species. For. Sci. 9:283-288.

Roeth, F.W., O.C. Burnside, and G.A. Wicks. 1983. Protection of grain sorghum (Sorghum bicolor) from chloroacetanilide herbicide injury. Weed Sci. 31:373-379.

Saxton, A.M. 1998. A macro for converting mean separation output to letter groupings in Proc Mixed. In: Proc. 23rd SAS Users Group Intl., SAS Institute, Cary, NC.

U.S. Department of Agriculture. 2006. Agricultural Chemical Usage 2005 Field Crops Summary. 29 July 2008. <http://jan-tng.mannlib.cornell.edu/ reports/nassr/other/pcu-bb/agcs0506.pdf $>$.

Wills, G.D. 1978. Factors affecting toxicity and translocation of glyphosate in cotton (Gossypium hirsutum). Weed Sci. 26:509-513.

Wisconsin Department of Agriculture, Trade and Consumer Protection. 2003. Wisconsin Pest Bulletin 48:73. 29 July 2008. <http://pestbulletin. wi.gov/ pdf/2003/June6web.pdfs. 